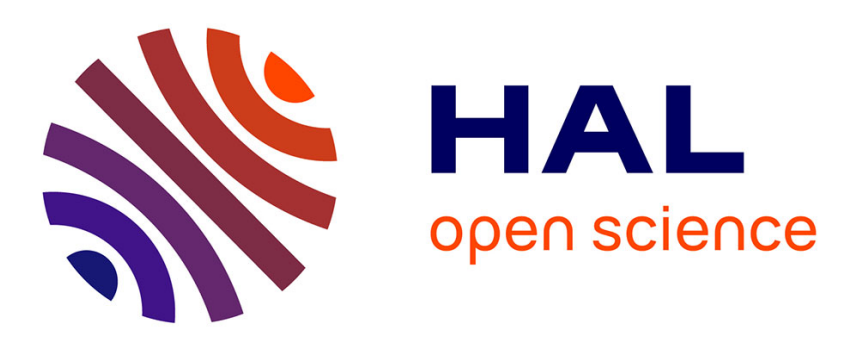

\title{
XAFS Studies on the Metal Ion (Cu, Ag) Photocatalysts Prepared Within Zeolite Cavities Using an Ion-Exchange Method
}

\author{
H. Yamashita, M. Matsuoka, M. Anpo, M. Che
}

\section{- To cite this version:}

H. Yamashita, M. Matsuoka, M. Anpo, M. Che. XAFS Studies on the Metal Ion (Cu, Ag) Photocatalysts Prepared Within Zeolite Cavities Using an Ion-Exchange Method. Journal de Physique IV Proceedings, 1997, 7 (C2), pp.C2-941-C2-942. 10.1051/jp4:1997292 . jpa-00255366

\section{HAL Id: jpa-00255366 https://hal.science/jpa-00255366}

Submitted on 1 Jan 1997

HAL is a multi-disciplinary open access archive for the deposit and dissemination of scientific research documents, whether they are published or not. The documents may come from teaching and research institutions in France or abroad, or from public or private research centers.
L'archive ouverte pluridisciplinaire HAL, est destinée au dépôt et à la diffusion de documents scientifiques de niveau recherche, publiés ou non, émanant des établissements d'enseignement et de recherche français ou étrangers, des laboratoires publics ou privés. 


\title{
XAFS Studies on the Metal Ion (Cu, Ag) Photocatalysts Prepared Within Zeolite Cavities Using an Ion-Exchange Method
}

\author{
H. Yamashita, M. Matsuoka, M. Anpo and M. Che*
}

\author{
Department of Applied Chemistry, College of Engineering, Osaka Prefecture University, Gakuen-cho, \\ Sakai, Osaka 593, Japan \\ * Laboratoire de Réactivité de Surface, Université Pierre et Marie Curie, URA 1106 du CNRS, \\ 4 place Jussieu, Tour 54, 75252 Paris cedex 05, France
}

\begin{abstract}
Using a combination of in-situ XAFS, photoluminescence and diffuse reflectance measurements, the characterization of the coordination geometry of metal $(\mathrm{Cu}, \mathrm{Ag})$ ion photocatalysts prepared within zeolites by an ion-exchange method and thermovacuum treatment has been carried out. The metal ions within zeolites were found to exist as isolated monomers, dimers and clusters, their relative concentration strongly depending of types of zeolites used. Within ZSM-5 and mordenite zeolites, most of the metal ions $\left(\mathrm{Cu}^{+}, \mathrm{Ag}^{+}\right)$were found to exist as isolated monomers with low coordinate numbers (planar 3 or linear 2 coordinate geometry), in contrast to the case of the $Y$-zeolite having dimers and/or clusters.
\end{abstract}

\section{INTRODUCTION}

It is of special interest to design the ion and/or cluster size photocatalysts within the zeolites having unique nanopore structure and ion-exchange capacities. Recently, we have found that the $\mathrm{Cu}^{+}$and $\mathrm{Ag}^{+}$ion photocatalysts included within zeolite cavities exhibit the high photocatalytic reactivity for NO decomposition and their reactivities much depend on the types of zeolites used [1-3]. In the present study, a combination of in-situ XAFS, photoluminescence and diffuse reflectance measurements has been applied to characterize the local environment of metal $(\mathrm{Cu}, \mathrm{Ag})$ ion photocatalysts prepared within various types of zeolites using ion-exchange method and thermovacuum treatment.

\section{EXPERIMENTAL}

Three types of zeolites and $\mathrm{SiO}_{2}\left(300 \mathrm{~m}^{2} / \mathrm{g}\right)$ were used as supports; $\mathrm{ZSM}-5\left(\mathrm{SiO}_{2} / \mathrm{Al}_{2} \mathrm{O}_{3}=23.3\right)$, Y-zeolite (5.5) and mordenite (14.9). $\mathrm{Cu}^{2+} /$ zeolite and $\mathrm{Ag}^{+} /$support samples were prepared by ion-exchange with aqueous $\left(\mathrm{Cu}\left(\mathrm{NH}_{3}\right) 4\right)_{2}^{2+}$ and $\mathrm{Ag}\left(\mathrm{NH}_{3}\right)_{2}{ }^{+}$solutions, respectively; the loadings as metal were 3.0 (ZSM-5), 2.6 (Y-zeolite) and 1.9 wt\% (mordenite) for $\mathrm{Cu}^{2+} /$ zeolite, 6.7 (ZSM-5), 6.5 (Y-zeolite) and $2.8 \mathrm{wt} \%\left(\mathrm{SiO}_{2}\right)$ for $\mathrm{Ag}^{+} /$support samples. The Cu $\mathrm{K}$-edge and $\mathrm{Ag} \mathrm{K}$-edge XAFS spectra were recorded in the transmission mode at $295 \mathrm{~K}$ at the BL-10B facility of the Photon Factory in Tsukuba.

\section{RESULTS AND DISCUSSION}

Figure 1 shows the XANES spectra of the $\mathrm{Cu}^{2+} / \mathrm{ZSM}-5$ sample (a) and $\mathrm{Cu}^{+} /$zeolite catalysts (b-d) prepared by the evacuation at $973 \mathrm{~K}$. The spectra of these samples exhibit four kinds of bands due to $1 \mathrm{~s}-3 \mathrm{~d}$ transition (A), 1s-4pz (1s-4p $\left.\pi^{*}\right)$

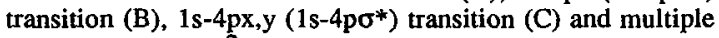
scattering (D). $\mathrm{Cu}^{2+} / \mathrm{ZSM}-5$ sample dried at $373 \mathrm{~K}$ shows a well-separated weak preedge band due to $1 \mathrm{~s}-3 \mathrm{~d}$ transition (A) and an intense band due to $1 \mathrm{~s}-4 \mathrm{p}(\mathrm{B}, \mathrm{C})$, accompanied by their shake-down bands $\left(\mathrm{B}^{\prime}, \mathrm{C}^{\prime}\right)$ indicating that the $\mathrm{Cu}^{2+} /$ zeolite samples contain predominantly $\mathrm{Cu}^{2+}$ ions having slightly distorted symmetries. The band due to $1 \mathrm{~s}-4 \mathrm{pz}(\mathrm{B})$ observed with $\mathrm{Cu}^{+} / 2 \mathrm{SM}-5$ and $\mathrm{Cu}^{+} /$mordenite catalysts is intense enough to identify the copper species as isolated $\mathrm{Cu}^{+}$ions with a planar 3 or a linear 2 coordinate geometry. Figure 1 also shows the corresponding FT-EXAFS spectra. $\mathrm{Cu}^{+} / \mathrm{ZSM}-5$ and $\mathrm{Cu}^{+} /$mordenite catalysts exhibit only a small peak which can be assigned to the neighboring $\mathrm{O}$ atoms $(\mathrm{Cu}-\mathrm{O})$, indicating that the isolated $\mathrm{Cu}^{+}$ions are present with 2 or 3-coordinate geometry. On the other hand, $\mathrm{Cu}^{+} / \mathrm{Y}$-zeolite exhibits an intense peak due to neighboring copper atoms $(\mathrm{Cu}-\mathrm{Cu})$ as well as $\mathrm{Cu}-\mathrm{O}$ peak, indicating the aggregation of $\mathrm{Cu}^{+}$ions. These $\mathrm{Cu}^{+} /$zeolite catalysts show a typical photoluminescence spectrum at around $400-600 \mathrm{~mm}$ at $77 \mathrm{~K}$ upon excitation at around $300 \mathrm{~nm}$. The excitation band at around $300 \mathrm{~nm}$ and the photoluminescence bands at around $400-500 \mathrm{~nm}$ are attributed to the electronic excitation of the $\mathrm{Cu}^{+}$ion $\left(3 \mathrm{~d}^{10} \rightarrow 3 \mathrm{~d}^{9} 4 \mathrm{~s}^{1}\right)$ and its reverse radiative deactivation $\left(3 \mathrm{~d}^{9} 4 \mathrm{~s}^{1} \rightarrow 3 \mathrm{~d}^{10}\right)$,
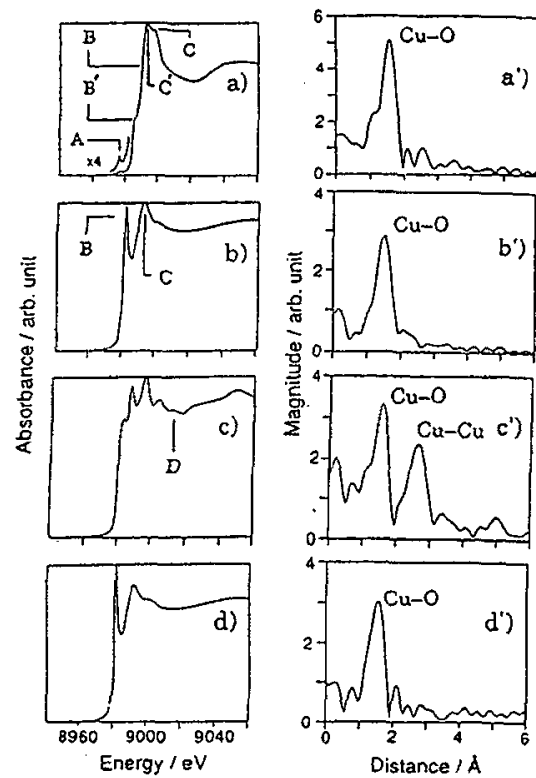

Figure 1. XANES (left) and FT-EXAFS (right) spectra of the $\left(a, a^{\prime}\right) \mathrm{Cu}^{2+} / Z$ ZSM-5 sample and $\left(b, b^{\prime}\right) \mathrm{Cu}^{+} / Z S M-5,\left(c, c^{\prime}\right) \mathrm{Cu}^{+} / Y$ zeolite and $\left(\mathrm{d}, \mathrm{d}^{\prime}\right) \mathrm{Cu}^{+} /$mordenite catalysts. (The catalysts were prepared by evacuation of the original $\mathrm{Cu}^{2+} /$ zeolite samples at $973 \mathrm{~K}$.). 
respectively. On the other hand, the photoluminescence band at around 500-600 $\mathrm{nm}$ is attributed to the presence of the $(\mathrm{Cu}+\ldots$ $\mathrm{Cu}^{+}$) dimer or high (more than 4) coordinated $\mathrm{Cu}^{+}$species. The results in Fig. 2 show that the photoluminescence band at around $430-460 \mathrm{~nm}$ is the major component for the $\mathrm{Cu}^{+} / \mathrm{ZSM}-5$ and $\mathrm{Cu}^{+} /$mordenite catalysts, while the $\mathrm{Cu}^{+} / \mathrm{Y}-\mathrm{zeolite}$ catalyst exhibits two different photoluminescence bands at around 450 and $525 \mathrm{~nm}$. These results clearly indicate that in the ZSM-5 and mordenite zeolites most of the copper ions exist as isolated $\mathrm{Cu}^{+}$monomer species, but in the $\mathrm{Y}$-zeolite both isolated $\mathrm{Cu}^{+}$and aggregated $\left(\mathrm{Cu}^{+}-\mathrm{Cu}^{+}\right)$dimer species are present, in good agreement with the results obtained by the $\mathrm{XAFS}$ measurements.

Figure 3 shows the XAFS spectra of the $\mathrm{Ag}^{+} /$zeolite and $\mathrm{Ag}^{+} / \mathrm{SiO}_{2}$ catalysts. In the FT-EXAFS spectra, $\mathrm{Ag}^{+} / \mathrm{ZSM}-5$ exhibits only a peak due to the neighboring $\mathrm{O}$ atoms $(\mathrm{Ag}-\mathrm{O})$ indicating the presence of the isolated $\mathrm{Ag}^{+}$ions. By the curvefitting analyses of this Ag-O peak, atomic distance and coordination numbers were obtained to be $2.15 \AA$ and 1.9 , respectively. On the other hand, the $\mathrm{Ag}^{+} / \mathrm{Y}$-zeolite and $\mathrm{Ag}^{+} / \mathrm{SiO}_{2}$ catalysts exhibit a peak due to the neighboring $\mathrm{Ag}$ atoms ( $\mathrm{Ag}-\mathrm{Ag}$ ) in addition to the $\mathrm{Ag}-\mathrm{O}$ peak, indicating that some parts of silver ions are reduced and aggregated to form $\mathrm{Ag}$ ion clusters or $\mathrm{Ag}$ metal particles. Figure 4 shows the diffuse reflectance spectra of these catalysts. The $\mathrm{Ag}^{+} / \mathrm{ZSM}^{-5}$ exhibits an intense absorption band at around $220 \mathrm{~nm}$ which is attributed to the $4 d^{10}-\rightarrow 4 d^{9} 5 s^{1}$ electronic transition on the $\mathrm{Ag}^{+}$ions. On the other hand, $\mathrm{Ag}^{+} / \mathrm{Y}$-zeolite and $\mathrm{Ag}^{+} / \mathrm{SiO}_{2}$ exhibit the broad absorption band in wavelength regions longer than $250 \mathrm{~nm}$ which can be assigned to the $\mathrm{Agn}^{\mathrm{O}}$ and $\mathrm{Agm}^{\mathrm{n}+}$ clusters. These results clearly indicate that in the ZSM-5 most of the silver ions exist as isolated $\mathrm{Ag}^{+}$monomers, but in the $\mathrm{Y}$-zeolite as well as on $\mathrm{SiO}_{2}$ the $\mathrm{Agn}^{0}$ and $\mathrm{Agm}^{\mathrm{n}+}$ clusters are formed, in good agreement with the results obtained by the XAFS measurements.

It can be expected that the metal ions $\left(\mathrm{Cu}^{+}, \mathrm{Ag}^{+}\right)$in the $\mathrm{Y}$-zeolite with large supercages may diffuse more easily to form the metal ions dimers or clusters, while in the narrow channels of ZSM-5 and mordenite, the metal ions are less mobile and form isolated $\mathrm{Cu}^{+}$or $\mathrm{Ag}^{+}$monomer species. In addition to these differences, the $\mathrm{Y}$-zeolite has a much higher density of ion-exchangeable sites than ZSM-5 and mordenite. This allows the metal ions to exist so close to each other that they aggregate easily during heating treatments.

In conclusions, the present in-situ XAFS investigations indicated that $\mathrm{Cu}^{+}$ions in the $\mathrm{ZSM}-5$ and mordenite zeolites exist as isolated $\mathrm{Cu}^{+}$monomers with planar 3 or linear 2 coordinate geometry while in the Y-zeolite they exist as the $\left(\mathrm{Cu}^{+} .-\right.$ $\mathrm{Cu}^{+}$) dimer species as well as the isolated $\mathrm{Cu}^{+}$monomer species. The $\mathrm{Ag}^{+}$ions prepared within ZSM-5 zeolites were also found to exist as isolated $\mathrm{Ag}^{+}$monomers with 2 coordinate geometry. These results indicate that the application of the ionexchange method and the use of ZSM-5 zeolites as supports are suitable and significant in the preparation of isolated metal ion photocatalysts with low coordinate numbers which exhibit high photocatalytic reactivity for NO decomposition [1-3].
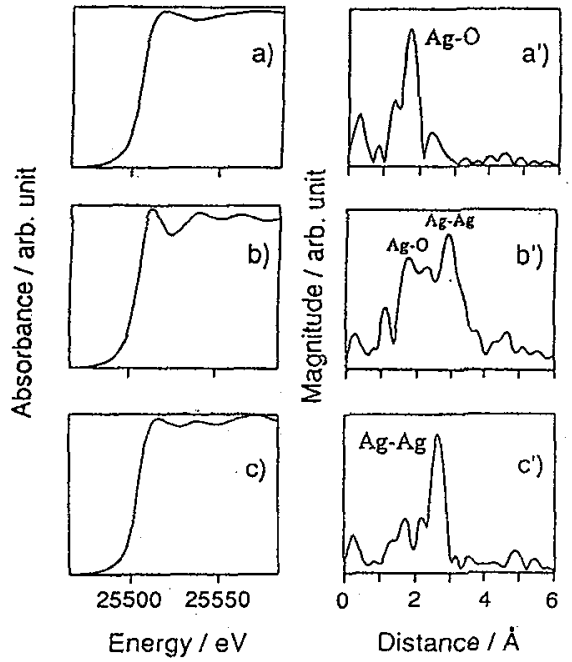

Figure 3. XANES (left) and FT-EXAFS (right) spectra of the (a,a) $\mathrm{Ag}^{+} / \mathrm{ZSM}-5,\left(\mathrm{~b}, \mathrm{~b}^{\prime}\right) \mathrm{Ag}^{+} / \mathrm{Y}$-zeolite and (c, $\left.\mathrm{c}^{+}\right) \mathrm{Ag}^{+} / \mathrm{SiO}_{2}$ catalysts. (The catalysts were prepared by calcination of the original $\mathrm{Ag}^{+} /$support samples at $673 \mathrm{~K}$ and evacuation at $473 \mathrm{~K}$.)

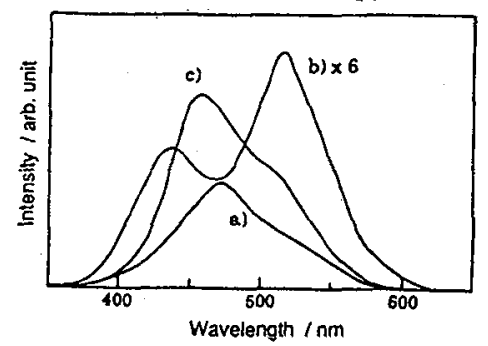

Figure 2. The photoluminescence spectra of the (a) $\mathrm{Cu}^{+} / \mathrm{ZSM}$ S, (b) $\mathrm{Cu}^{+} / \mathrm{Y}$-zeolite and (c) $\mathrm{Cu}^{+} /$mordenite catalysts measured at $77 \mathrm{~K}$.

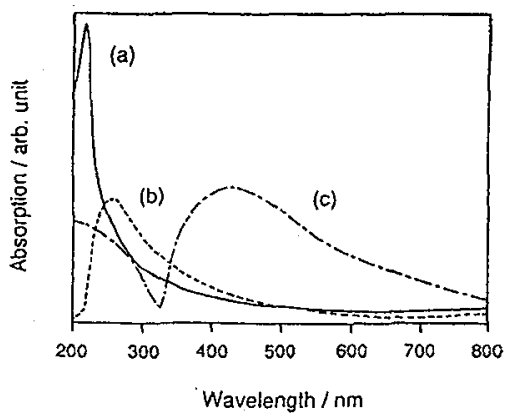

Figure 4. Diffuse reflectance spectra of the $\left(a, a^{\prime}\right) \mathrm{Ag}^{+} / Z \mathrm{SM}-5$, (b, b') $\mathrm{Ag}^{+/} / \mathrm{Y}$-zeolite and (c,c') $\mathrm{Ag}^{+} / \mathrm{SiO}_{2}$ catalysts.

References

[1] Anpo M., Matsoka M., Shioya Y., Yamashita H., Giamello E., Morterra C., Che M., Paterson H. H., Webber S., Webber S., Ouellette S., and Fox M. A., J. Phys. Chem., 98 (1994) 5744-5750.

[2] Yamashita H., Matsoka M., Tsuiji K., Shioya Y., Anpo M., Che H. M., and Fox M. A., J. Phy.s. Chem., 100 (1996) $397-402$.

[3] Matuoka, M., Matsuda, E., Tsuji, K., Yamashita, H., and Anpo, M., J. Mol. Catal. A: Chem., 107 (1996) 399-403. 